\title{
The United States Ban on \\ Tourism to Cuba
}

\author{
FRANK J. VANDALL*
}

\section{TABLE OF CONTENTS}

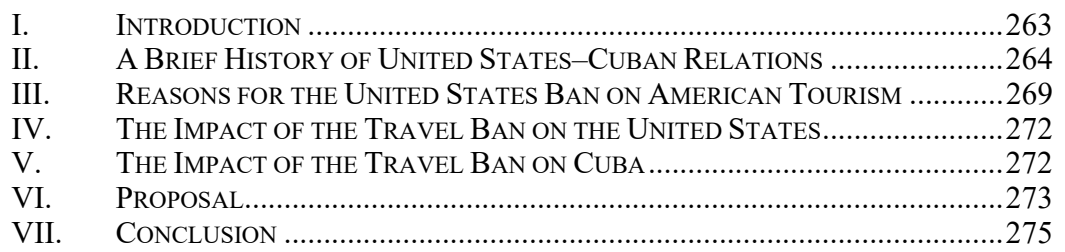

\section{INTRODUCTION}

The purpose of this Article is to evaluate the United States ban on Americans' touring Cuba. ${ }^{1}$ This Article begins with the history of the United States' tumultuous relations with Cuba over the past 60 years, then it explores the specific language of the ban and the reasons presented for it. Additionally, the Article considers the impact of the new law on both the United States and Cuba and concludes with an argument for lifting the

* $\quad$ (C) 2021 Frank J. Vandall. Professor of Law, Emory University School of Law. B.A. 1964, Washington, and Jefferson College; J.D. 1967, Vanderbilt University School of Law; L.L.M. 1968, S.J.D. 1979, University of Wisconsin Law School. I appreciate the research assistance of Victoria Miller. Mistakes are mine, however.

1. Press Release, U.S. Dep't of the Treasury Office of Public Affairs, Treasury Issues Changes to Strengthen Cuba Sanctions Rules (Sept. 6, 2019), https://www.treasury.gov/ resource-center/sanctions/Programs/Documents/cuba_fact_sheet_20190906.pdf [https:// perma.cc/85QK-MKS9]. 
ban and returning to the policy of normalization that preexisted the declaration.

\section{A BRIEF History OF UNITED STATES-CUBAN RELATIONS}

Prior to 1959 , Cuba was governed by a dictator who was supported by the United States, Fulgencio Batista. ${ }^{2}$ He is well remembered for developing Havana into one of the gambling capitals of the world. ${ }^{3}$ The problem for Cuba was that the United States played a significant role in Cuba's government. ${ }^{4}$ This helped precipitate Fidel Castro's revolution of $1959 . .^{5}$ It was nearly bloodless as President Batista fled and Fidel Castro took over the reins. ${ }^{6}$

In response to the revolution, the United States imposed an extensive embargo on most things, including energy and food. ${ }^{7}$ Castro needed help

2. See Frank Argote-Freyre, Fulgencio Batista: The Making of A Dictator 186 (Rutgers Univ. Press 2006) (noting that the United States connived with Batista and allies to rig the Cuban presidential elections).

3. Id. at 24 (citing De Portell Villa Herminio, Nueva Historia de la Republica de CuBA 360 (1986)).

4. Simon Worrall, When the Mob Owned Cuba, SMITHSONIAN JOURNEYs Q. (Oct. 28, 2016), https://www.smithsonianmag.com/travel/mob-havana-cuba-culture-musicbook-tj-english-cultural-travel-180960610 [https://perma.cc/8D7N-2WB8] ("The mob funneled dirty money into Cuba to build casinos and hotels, which in turn generated the funds used to facilitate the corrupt political system led by President Fulgencio Batista."); see Thomas Carothers, Backing the Wrong Tyrant, N.Y. Times (June 4, 1994), https:// www.nytimes.com/1994/06/12/books/backing-the-wrong-tyrant.html [https://perma.cc/ W5VS-VKNN] ("Washington policy makers [were] secure in their belief that Cuba was dependent on the U.S. [and failed] to appreciate the damage of Batista's corruption and repression ....").

5. Historically, a team of revolutionaries, including Che Guevara and the Castro brothers overthrew the Cuban dictator Fulgencio Batista. JANE FRANKLIN, CUBA AND THE United States: A Chronological History 129 (Ocean Press 1997). Fidel Castro was elected President of Cuba in 1976. Id. Castro was Cuba's unchallenged leader since 1959. One of his first accomplishments was to nationalize the private land and turn Cuba into a communist state. The nationalization of the land is the heart of the United States' disagreement with Cuba today.

6. The state took the private land in Cuba and redistributed it to other Cuban citizens. Specifically, "The Cuban government enact[ed] the first Agrarian Reform Law, putting a limit on land holdings and expropriating the remainder .... The expropriated land along with land already owned by the state will be transferred to cooperatives or distributed free of charge ...." That was over fifty years ago and is not likely to change, except perhaps through a negotiated settlement. Matias F. Travieso-Diaz, Alternative Remedies in a Negotiated Settlement of the U.S. Nationals' Expropriation Claims Against Cuba, 17 U. PA. J. INT'L ECON. L. 659 (1996).

7. 23 U.S.C. $\S 2370$ (a)(1). In 1960, President Eisenhower approved an anti-Castro plan, which included an embargo on sugar, oil, and guns. Post-Revolution Cuba, PuB. BROAD. SERV. (2005), https://www.pbs.org/wgbh/americanexperience/features/post-revolutioncuba/ [https://perma.cc/6R5D-QA6M]. 
with many essential goods and, therefore, began to look to Russia for assistance, trading Cuban sugar in return for Russian oil. ${ }^{8}$ In 1962 , Russian aid stopped and the Cuban people nearly starved. ${ }^{9}$ They ate what they could find, including non-conventional food. ${ }^{10}$ Both the King Ranch that originated in Texas and Bacardi rum were driven out of Cuba because

8. Cuba's necessity for foreign assistance was real. Ed Sanders \& Patrick Long, Economic Benefits to the United States from Lifting the Ban on Travel to Cuba, CuBA POL'Y FOUND. (June 2002), https://www.researchgate.net/publication/266249806 Economic Benefits to the United States from Lifting the Ban on Travel to Cuba Prepared by [https://perma.cc/V7JL-LM2X] ("The impact of the embargo has been devastating to the island nation. Cuba went from being the number one Caribbean tourist destination in 1958 to attracting only 12,000 visitors in 1974."); Cuba was once the world's third largest sugar producer and largest sugar exporter. OFF. OF GLOB. ANALYSIS, U.S. Dep'T OF Agric., CubA's Food \& Agriculture Situation Report (Mar. 2008), https://thecubaneconomy.com/wp-content/uploads/2012/02/Cuba $\% E 2 \% 80 \% 99$ s-FoodAgriculture-Situation-Report-USDA-2008.pdf [https://perma.cc/85P8-6E5W] ("But sugar eventually proved to be the key mechanism for the Soviets to provide economic support for the new Castro government ....").

9. Andrew Damitio, The Lessons from Cuba's "Special Period", Medium (Oct. 29, 2018), https://medium.com/datadriveninvestor/the-lessons-from-cubas-specialperiod-980d0d15849e [https://perma.cc/K6D9-KWPN] ("Between 1989 and 1991,... [t]he nation's cattle population was nearly wiped out by the hungry population, and even household cats were eaten. Animals in the Havana zoo were not spared either. The average weight of Cubans fell by 12 pounds in the ordeal."); see also ANDREW ZIMBALIST, TrEading Water: CubA's ECONOMiC AND Political CRisis, in Cuba AND THE Future 7, 7 (Donald E. Schulz ed., 1994) ("[T] the Soviet Union."); Danielle M. Hall, Bienvenidos a Cuba (Part II): A Look Into an Unfamiliar Justice System, 81 J. KAN. BAR Ass'N 19-21 (Sept. 2012); Stuart Grider, A Proposal for the Marketization of Housing in Cuba: The Limited Equity Housing Corporation - A New Form of Property, 27 U. MiA. INTER-AM. L. REV. 453, 462 (1996) (citing Kathleen Barrett, The EFFect of the Collapse of the Soviet Union AND Eastern Bloc on the Cuban Health Care System (May 1992)); Off. of Glob. ANALYSIS, supra note 8. Oil became so scarce that many locals forwent their automobiles and tractors in favor of bicycles and ox-drawn plows. Grider, supra note 9, at 462. By 2008, Cuba's sugar industry accounted for slightly more than $10 \%$ of the volume it was producing in the 1980s. OFF. OF GLOB. ANALYSIS, supra note 8.

10. See Mario J. Pentón, Cuba's Latest Remedy to Ease Food Shortage? African Ostriches, MiA. HeRAld (Apr. 10, 2019), https:/www.miamiherald.com/news/nationworld/world/americas/cuba/article229082734.html [https://perma.cc/XJ3R-KYC5] (noting that the island could eat rats such as nutria and will begin breeding cows and crocodiles to increase the amount of food available, and that a variety of non-conventional foods were eaten before and during the Special Period). 
they were privately owned. ${ }^{11}$ To this day, beef is quite expensive in Cuba. ${ }^{12}$

President John F. Kennedy supported a disastrous invasion of Cuba in 1962 known as the Bay of Pigs. ${ }^{13}$ The United States' expectation was that Cubans would oppose Castro's communism and rush to the side of the United States during the invasion. ${ }^{14}$ The opposite happened when Cubans supported Castro and the American invasion was crushed. ${ }^{15}$

This loss precipitated an expanded Cuban trade embargo and a ban on Americans visiting Cuba. ${ }^{16}$ Congress passed the Helms-Burton Act, which formalized the embargo and tourism ban. ${ }^{17}$ President Clinton, however, eased the embargo and the ban by executive order. ${ }^{18}$ This liberalization was rejected by President George Bush, who again tightened the restrictions on Cuban travel. ${ }^{19}$ This came as a response to pressure from Cuban Americans living

11. King's Ranch was transferred to Cuba and then to Russia. BETTY BAILEY COLLEY ET AL., Showmen of King Ranch: The Story of Beto And Librado Maldonado 24-26 (Univ. of Tex. Press 2009); Jack Guy, Cuba and Bacardi: A Complicated History, CULTURE TRIP (Oct. 10, 2017), https://theculturetrip.com/caribbean/cuba/articles/cubaand-bacardi-a-complicated-history/ [https://perma.cc/PF9W-WUB7] ("While the Bacardi family supported the rebels and donated money to the cause at first, they then opposed developments as the revolutionaries went against the interests of the company. Luckily for them, significant trademarks and operations had been transferred out of Cuba by the time Fidel Castro confiscated the company assets without compensation after he took power.").

12. Castro expropriated the King Ranch, which produced beef-cattle. The King Ranch became nonfunctional due to deterioration, which led to it being used as a mere tourist attraction. Given these events, beef is still very expensive in Cuba. See COLLEY ET AL., supra note 11, at 24-25; Osmel Ramirez Alvarez, Will Beef Ever Be Eaten Freely in Cuba Again?, HAVANA TIMES (May 18, 2016), https://havanatimes.org/opinion/will-beefever-be-eaten-freely-in-cuba-again/ [https://perma.cc/RE5T-SBR2].

13. Mark White, Bay of Pigs Invasion: Kennedy's Cuban Catastrophe, Hist. EXTRA (Apr. 17, 2018), https://www.historyextra.com/period/20th-century/bay-of-pigs-invasionkennedys-cuban-catastrophe/ [https://perma.cc/T97H-7FW2].

14. See id. (Although Kennedy was provided with intelligence that suggested the Cuban people would not accept this, "He should have taken on board British intelligence information he received early in his presidency that suggested Cubans were unlikely to react to a Cuban exile invasion by rising up against Castro.")

15. Id.

16. U.S.-Cuba Relations, Council on Foreign Rels. (Mar. 27, 2020), https:// www.cfr.org/backgrounder/us-cuba-relations [https://perma.cc/H7L6-PHD2].

17. Cuban Liberty and Democratic Solidarity (LIBERTAD) Act of 1996, Pub. L. No. 110-114, 110 Stat. 785, §§ 101-116 (1996) (codified in 22 U.S.C. $§ 6021$ ).

18. Jack Nelson, Clinton Backs Bill to Ease Cuba Embargo, L.A. TIMES (Apr. 14, 1998), https://www.latimes.com/archives/la-xpm-1998-apr-14-mn-39145-story.html [https:// perma.cc/PN9Z-FGDF] ("The Clinton administration ... is working behind the scene to marshal support for bipartisan legislation to exempt food and medicine from the U.S. trade embargo against Cuba .... Clinton act[ed] 'alone' in recently issuing an executive order that eas[ed] curbs on sending medicine and money to Cuba.").

19. President George Bush, President Bush Discusses Cuba Policy in Rose Garden Speech (Oct. 10, 2003), at https://georgewbush-whitehouse.archives.gov/news/releases/2003/ 10/20031010-2.htm) [https://perma.cc/QBJ7-C6LZ]; Bush Reaffirms Cuba Embargo, 
in Florida whose Cuban property and businesses had been expropriated. ${ }^{20}$ They rallied against Castro because of the loss of their property. ${ }^{21}$

President Obama loosened many of these restrictions, however. ${ }^{22}$ Travel to Cuba by Americans expanded under President Obama. ${ }^{23}$ But for the present U.S. travel ban, perhaps 420,000 Americans would have visited by cruise ships and 300,000 by plane during $2019 .{ }^{24}$ Cuba was poised for the influx of tourism as it had begun to experiment with free market economic policies. ${ }^{25}$ Privately owned restaurants sprang-up under Obama's relaxation of the travel ban as did small private hotels. ${ }^{26}$ Farmers were permitted by the Cuban government, for the first time, to hold-back and sell for themselves a portion of their crops. ${ }^{27}$

CNN POLITICS (Oct. 25, 2007), https://www.cnn.com/2007/POLITICS/10/25/bush.cuba/ [https://perma.cc/5UH3-UY6G].

20. Some Cuban Americans had their Cuban property seized. Carmen Sesin, Claims Under Cuba Seized Property Law Are Fewer Than Expected, NBC NEws (June 3, 2019, 9:37 AM), https://www.nbcnews.com/news/latino/claims-under-cuban-seizedproperty-law-are-fewer-expected-n1010961 [https://perma.cc/7BFR-FTYT]. See Susan Eckstein, How Cubans Transformed Florida Politics and Leveraged Local for National Political Influence, FL. Scholarship Online 21 (2015) (“[T] gain support of three fourths of Floridian Cuban Americans, Bush acceded to pressure from influential Exiles to tighten the personal embargo, one of the few remaining loopholes in the embargo.").

21. Cuban Exiles in America, PUB. BROAD. SERV. (2005), https://www.pbs.org/ wgbh/americanexperience/features/castro-cuban-exiles-america/ [https://perma.cc/8QPNEUB9].

22. Press Release, President Barack Obama, Presidential Statement on Cuba Policy Changes Cabinet Room (Dec. 17, 2014, 12:01 PM), https://obamawhitehouse.archives.gov/ the-press-office/2014/12/17/statement-president-cuba-policy-changes; U.S.-Cuba Relations, supra note 16.

23. U.S.-Cuba Relations, supra note 16.

24. See Tariro Mzezewa, New Rules on American Travel to Cuba Include Cruise Ban, N.Y. TimES (June 4, 2019), https://www.nytimes.com/2019/06/04/travel/cuba-travelrestrictions-trump.html [https://perma.cc/Z3S2-K5VJ] ("This year [2019], between January 1 and April 30, 142,721 Americans went to Cuba on cruises, compared to the 114,832 who traveled there by plane.").

25. Damien Cave, With Obama Visit to Cuba, Old Battle Lines Fade, N.Y. TIMES (Mar. 26, 2016), https://www.nytimes.com/2016/03/27/world/americas/with-obama-visitto-cuba-old-battle-lines-fade.html [https://perma.cc/QWB4-XSE2].

26. Marc Frank, Cuban State Begins to Move Out of the Restaurant Business, REUTERS (Aug. 26, 2013, 11:55 AM), https://www.reuters.com/article/us-cuba-reformcooperatives/cuban-state-begins-to-move-out-of-the-restaurant-business-idUSBRE97P0R 620130826 [https://perma.cc/R2BU-HMKD] ("[In 2013], there [were] close to 2,000 private restaurants as local entrepreneurs [took] advantage of market-oriented reforms initiated by President Raul Castro, who took over for his ailing older brother Fidel in 2008.”).

27. Tour guide's statement to the author in a visit to Cuba in 2017. 
President Obama granted licenses to companies to provide tours to Cuba under the people-to-people concept. ${ }^{28}$ Visits could not be purely recreational, but rather, they were allowed for cultural and educational purposes only. ${ }^{29}$ When I visited Cuba three years ago under the people-topeople agreement, I saw professional dancers, musicians, and singers. I also visited a day care center and the remains of the King Ranch. The Cuban artists were charming, outgoing, and pleased to answer nonpolitical questions after their performances. I was able to see the reality of communismshortages of oil, basic foods, and car parts. ${ }^{30}$

On March 20, 2016, President Obama and the First Lady visited Cuba in a show of support for improved relations and received a friendly reception. ${ }^{31}$ Their visit was the highpoint of contemporary Cuban American relations.

The United States first started to ratchet down on Cuba when it began to permit lawsuits against the Cuban government and persons using property that had been expropriated by the Cuban regime. ${ }^{32}$ For example, Carnival Cruise Line was sued for using Cuban docks that had been privately owned but were seized after the Cuban revolution. ${ }^{33}$

This dramatic change in U.S. policy was followed by a presidential ban on cultural and educational visits, which is the subject of this Article. ${ }^{34}$ This travel ban provided that "the United States will not permit group educational and cultural trips known as 'people to people' trips to [Cuba] ... [n]or will it allow cruises, private yachts or fishing vessels to stop in Cuba." 35

28. Support for the Cuban People, 31 C.F.R. $\S 515.574$ (2015).

29. See id.

30. Some antique American cars now use Russian diesel engines because parts from the United States are embargoed. See Will Grant, The Cars of the Cuban Trade Embargo, BBC News (Aug. 13, 2015), https://www.bbc.com/news/magazine-33884714 [https://perma.cc/ 4DWK-SV2G]

31. Dan Roberts, Obama Lands in Cuba as First US President to Visit in Nearly a Century, GUARDIAN (Mar. 21, 2016), https:/www.theguardian.com/world/2016/mar/20/ barack-obama-cuba-visit-us-politics-shift-public-opinion-diplomacy [https://perma.cc/ VXD3-BH33].

32. U.S.-Cuba Relations, supra note 16.

33. Carrie Kahn, Suits Filed Against Carnival Cruises, Cuban Firms Over Seized Property in Cuba, NAT'L PUB. RADIO (May 7, 2019, 3:51 PM), https://www.npr.org/2019/ 05/07/720695420/suits-filed-against-carnival-cruises-cuban-firms-over-seized-propertyin-cuba [https://perma.cc/KZ2N-T96S].

34. See U.S.-Cuba Relations, supra note 16.

35. Tariro Mzezewa, New Rules on American Travel to Cuba Include Cruise Ban, N.Y. Times (June 4, 2019), https://www.nytimes.com/2019/06/04/travel/cuba-travelrestrictions-trump.html [https://perma.cc/36HX-Y8H7]; see also Press Release, U.S. Dep't of Treasury, Treasury and Commerce Implement Changes to Cuba Sanctions Rules (June 4, 2019), https://home.treasury.gov/news/press-releases/sm700 [https://perma.cc/HU88NRTK]. 
Nine Cuban airports were included in an expansion of the flight ban, leaving the Havana José Martí International Airport as an exemption. ${ }^{36}$ The reason for exempting the Havana Airport from the travel ban was to enable Cuban Americans to visit their families. ${ }^{37}$ Exceptions to the travel ban include visits related to education, journalism, and sports. ${ }^{38}$

\section{REASONS FOR THE UNITED STATES BAN ON AMERICAN TOURISM}

Three reasons have been presented for the travel ban. First, President Trump wanted to punish the Cuban government for providing troops to the President of Venezuela, Nicolás Maduro. ${ }^{39}$ President Trump viewed Maduro as a socialist and preferred Juan Guaidó who was democratically elected but blocked from taking office. ${ }^{40}$

36. Press Release, U.S. Secretary of State Michael R. Pompeo, U.S. Department of State, United States Further Restricts Air Travel to Cuba (Jan. 10, 2020), https://www. state.gov/united-states-further-restricts-air-travel-to-cuba/ [https://perma.cc/WXZ9-VDYB].

37. See Letter from Michael R. Pompeo, Secretary of State, to Elaine L. Chao, Secretary of Transportation (Jan. 7, 2020) (on file with Regulations.gov) ("Maintaining and capping public charter flights to José Martí International Airport preserves the main gateway for travel from the United States to Cuba for family visitation or other lawful purposes . ...") [hereinafter Suspending Cuba].

38. Traveling to Cuba, U.S. EMBASSY IN CUBA, https://cu.usembassy.gov/u-scitizen-services/local-resources-of-u-s-citizens/traveling-to-cuba/ [https://perma.cc/B92JAA6G].

39. Notice, David E. Short, Deputy Assistant Secretary, Aviation and International Affairs (Jan. 10, 2020) (on file with Regulations.gov) ("The Department is taking this action at the request of the U.S. Department of State. By letter dated January 7, 2020, Secretary of State Michael R. Pompeo wrote to Secretary of Transportation Elaine L. Chao, stating that: To strengthen the impact of the Administration's policy of applying economic pressure on the Cuban regime to respect human rights and fundamental freedoms for all in Cuba and to cease its unconscionable support for the illegitimate and totalitarian regime of former President Maduro in Venezuela, and in the foreign policy interests of the United States, I respectfully request that the Department of Transportation suspend until further notice all public charter flights between the United States and all airports in Cuba except José Martí International Airport (HAV) in Havana."); Adam Taylor, How Many Cuban Troops Are There in Venezuela? The U.S. Says Over 20,000. Cuba Says Zero, WASH. Post (May 2, 2019, 9:39 AM), https://www.washingtonpost.com/ world/2019/05/02/how-many-cuban-troops-are-there-venezuela-us-says-over-cuba-sayszero/ [https://perma.cc/KKY9-WPAT] ("“I think it is the fear of 20,000 to 25,000 Cuban security forces in [Venezuela]' that prevented Venezuelan troops from heeding Guaidó's call ....').

40. Anthony Faiola, Maduro Says He's Still in Control of Venezuela, Ready for Direct Talks With the United States, WASH. POST (Jan. 18, 2020, 6:45 PM), https://www.washingtonpost. $\mathrm{com} /$ world/the_americas/maduro-says-hes-still-in-control-of-venezuela-ready-for-direct- 
It is important to note that Cuba heavily relies on oil from Venezuela. ${ }^{41}$ Without this oil, many segments of Cuba could suffer. ${ }^{42}$ The goal of the United States is to pressure the Cuban economy in order to persuade the Cuban government to remove "troops" from Venezuela and force Maduro to resign. ${ }^{43}$

The second reason for the travel ban was to embrace and support Florida's Cuban American voters, many of whom have parents who emigrated to Florida from Cuba. ${ }^{44}$ Many Cuban Americans owned land in

talks-with-the-united-states/2020/01/18/7f609a6e-38a7-11ea-a1ff-c48c1d59a4a1_story.html [https://perma.cc/LA2U-NZXU].

41. John Otis, Cuba's Reliance Upon Venezuela for Cheap Oil Looms as Potential Threat, WaLl ST. J. (Feb. 26, 2019, 6:36 PM) https://www.wsj.com/articles/cubas-relianceupon-venezuela-for-cheap-oil-looms-as-potential-threat-11551224164 [https://perma.cc/ 4AK6-BXYT].

42. See id.

43. See Press Release, U.S. Dep't of Treasury, Treasury Sanctions Cos. Operating in the Oil Sector of the Venez. Econ. and Transporting Oil to Cuba (Apr. 5, 2019), https://home.treasury.gov/news/press-releases/sm643 [https://perma.cc/6R6Y-76LP] ("“Cuba has been an underlying force fueling Venezuela's descent into crisis. Treasury is taking action against vessels and entities transporting oil, providing a lifeline to keep the illegitimate Maduro regime afloat,' said Treasury Secretary Steven T. Mnuchin. 'Cuba continues to profit from, and prop up, the illegitimate Maduro regime through oil-for-repression schemes as they attempt to keep Maduro in power. The United States remains committed to a transition to democracy in Venezuela and to holding the Cuban regime accountable for its direct involvement in Venezuela's demise."'); see also Taylor, supra note 39.

44. A fair question is where the former owners of Cuban land are today. The answer is that many of them now live in Florida, although that is not completely accurate. See James S. Olson \& Judith E. Olson, Cuban Americans: From Trauma to Triumph 109 (1995). Most of the elite former landowners are now deceased. See id. ("At the turn of the century, most of the first-wave Cuban immigrants will be elderly people, and by 2010 most of them will be [deceased]."). It is their children who now wage "war" with Cuba and support the embargo. See Greg Allen, Children of Cuba Remember Their Flight to America, NAT'L PuB. RADIO (Nov. 19, 2011, 8:21 AM), http://www.npr.org/2011/11/19/ 142534943/pedro-pan-childrens-life-altering-flight-from-cuba [https://perma.cc/4RMZ3CV7] ("There's something ... that most of the Pedro Pan kids still share, 50 years later. They're firmly opposed to any normalization of relations with the Castro regime ....”). While Florida Senator Marco Rubio claims his parents were Cuban exiles, they left Cuba before the revolution and then chose not to return after it became clear that Cuba was headed toward communism under Fidel Castro. Manuel Roig-Franzia, Marco Rubio's Compelling Family Story Embellishes Facts, Documents Show, WasH. Post (Oct. 21, 2011), https://www.washingtonpost.com/politics/marco-rubios-compelling-family-storyembellishes-facts-documents-show/2011/10/20/gIQAaVHD1L_story.html [https://perma.cc/ L7Z3-8CK6]. The offspring have an alternative solution at hand to have the property returned; they can sue for justice in the World Court under the United States. See The Court, INT'L CT. OF JUST., https://www.icj-cij.org/en/court [https://perma.cc/CH94-SB7S] ("The Court's role is to settle, in accordance with international law, legal disputes submitted to it by States and to give advisory opinions on legal questions referred to it by authorized United Nations organs and specialized agencies."). The United States could bring suit on behalf of children of the original landowners. See id. 
Cuba before the revolution. ${ }^{45}$ Of substantial importance, however, is that Florida was a key state in President Trump's 2020 reelection plans. ${ }^{46}$

The third reason for the travel ban is President Trump's dislike of having a Communist country in his backyard, ${ }^{47}$ as Cuba is only 103 miles from Florida. ${ }^{48}$ This reason rings hollow, however, in light of President Trump's friendship with the three largest and most powerful "communist" countries in the world - China, Russia, and North Korea. ${ }^{49}$

45. See Kahn, supra note 33.

46. Marc Caputo, Ground Zero for Trump 2020 Campaign: Florida, POLITICO (May 9, 2019, 12:26 PM), https://www.politico.com/story/2019/05/09/trump-2020campaign-florida-1313622 [https://perma.cc/KNX6-9V6Z] ("In a sign of Florida's crucial importance to his winning a second White House term, Trump's campaign announced that the largest swing state in the nation would be considered its own geographical region when it comes to chain of command and allocation of resources.").

47. The three-hundred-pound gorilla at the table is the fact that Cuba is a communist government. See Nancy San Martin, Trump's Anti-Communist Foreign Policy Won Florida Hispanics, ForeIGN POL'y (Nov. 6, 2020, 1:17 PM) https://foreignpolicy.com/2020/11/06/ trump-anti-communist-foreign-policy-won-florida-hispanics-latino-cuban-vote-miamidade/ [https://perma.cc/CB2A-GR2B].

48. Diana Nyad, Cuba: So Close You Could Almost Swim There, Huffington Post (Jan. 29, 2015, 10:38 AM), https://www.huffpost.com/entry/cuba-so-close-you-coulda_b_6571342 [https://perma.cc/Z37H-WMVY].

49. President Nixon opened China to trade with the United States forty years ago. Stephen E. Ambrose, Nixon Volume II: The Triumph of A Politician 1962-1972 439 (1989). Today China is a huge trading partner. Top Trading Partners - March 2012, U.S. CENSUS BUREAU, https://www.census.gov/foreign-trade/statistics/highlights/top/top1203yr.html [https://perma.cc/4WNG-FGMZ] (listing China as the third-largest trading partner of the United States); David Barboza, China's Treasury Holdings Make U.S. Woes Its Own, N.Y. TIMES (July 19, 2011), https://archive.nytimes.com/query.nytimes.com/gst/fullpage9D04E3DF143CF93AA25754C0A9679D8B63.html [https://perma.cc/X2GT-CCNR] (listing China as the United States' largest creditor). Russia, a formerly communist nation, adopted numerous democratic reforms, such as free elections. See MichaEl McFAul ET al., Between Dictatorship and Democracy: Russia Post-communist Political REFORM 23 (2004) ("The advent of competitive elections in the Soviet Union and then Russia certainly contributed to the reclassification of the country as a democracy."). Trump: Putin Is Better Leader Than Obama, DAILY BEAST (Apr. 13, 2017, 3:03 PM), https://www.thedailybeast.com/cheats/2016/09/07/trump-putin-is-better-leader-thanobama [https://perma.cc/FEZ2-D957] ("The man has very strong control over a country,' he said. 'Now, it's a very different system and I don't happen to like the system, but certainly in that system, he's been a leader. Far more than our president has been a leader.' Trump added: 'I think I would have a very, very good relationship with Putin. I think I would have a very, very good relationship with Russia."'); Trump and Kim in Quotes: From Bitter Rivalry to Unlikely Bromance, AL JAZEERA (Feb. 27, 2019), https://www.aljazeera. com/news/2019/2/28/trump-and-kim-in-quotes-from-bitter-rivalry-to-unlikely-bromance [https://perma.cc/4FTC-HU6A] ("Trump described Kim as a 'great leader' and said his country had 'tremendous economic potential, unbelievable, unlimited' as he vowed to 


\section{THE IMPACT OF THE TRAVEL BAN ON THE UNITED STATES}

The most substantial impact of the travel ban was to forbid U.S. citizens from visiting Cuba. The travel ban defies the Fifth Amendment of the United States Constitution, however. The Fifth Amendment provides, "No person shall be ... deprived of life [or] liberty ... without due process of law. . . ." ${ }^{, 50}$ In 1958, the U.S. Supreme Court held that liberty includes the freedom to travel without governmental interference. ${ }^{51}$ Regarding the travel ban, no "due process" has been given to U.S. citizens as no hearings have been provided. Hearings have not been required because the ban rests on the Helms-Burton Act. ${ }^{52}$

In the Declaration on the Right to Development, the United Nations states that all individuals have a right to economic growth and prosperity. ${ }^{53}$ In contrast to the Declaration on the Right to Development, the clear goal of the U.S. travel ban is to pressure Cuba's economy. The travel ban will have a substantial impact on Cuba's growth and prosperity.

\section{THE IMPACT OF THE TRAVEL BAN ON CUBA}

The United States ranks number two, behind Canada, in the volume of tourists visiting Cuba. ${ }^{54}$ With a reduction in a substantial number of American visitors, every citizen of Cuba will suffer. ${ }^{55}$ Former Treasury Secretary Steven Mnuchin states that the ban is aimed to pressure the supporters of Venezuelan

'help' North Korea achieve those goals.”). For me, the visit to Cuba was an affirmation of our democratic form of government.

50. U.S. CONST. amend. V.

51. Kent v. Dulles, 357 U.S. 116, 125-27 (1958) ("The right to travel is a part of the "liberty" of which a citizen cannot be deprived without due process of law under the Fifth Amendment.").

52. The Helms-Burton Act codified the Cuban embargo into law. The Trade Sanctions Reform and Export Enhancement Act of 2000 furthered the Cuban embargo by prohibiting the Secretary of Treasury from authorizing travel to Cuba for tourist activities. President G.W. Bush used this language as the legal basis for restricting the citizens right to travel - a strategy used by President Trump as well. Peter Kornbluh, Congress Finally Challenges the Cuba Travel Ban, NATION (Aug. 1, 2019), https://www.thenation.com/ article/archive/cuba-travel-ban-congress-trump-leahy/ [https://perma.cc/T43K-N7VY].

53. G.A. Res. 41/128, Declaration on the Right to Development, at 1 (Dec. 4, 1986).

54. Tourism. Arrivals of International Visitors, REPUBLIC OF CUBA NAT'L OFF. OF STAT. \& INFO., http://www.onei.gob.cu/node/14859 [https://perma.cc/38VG-FKQL] (noting that in 2019, the United States had the second highest number of tourists visiting Cuba).

55. Nelson Acosta \& Sarah Marsh, Cuba Sees Tourism Dropping 8.5\% due to Trump Travel Restriction, REUTERS (July 11, 2019, 2:21 PM), https://www.reuters.com/article/ us-cuba-tourism/cuba-sees-tourism-dropping-8-5-due-to-trump-travel-restrictions-idUSKC N1U62UR [https://perma.cc/9SPS-CKLS]. 
oppression. ${ }^{56}$ In order to impact the Cuban government, U.S. policies must first negatively impact the Cuban people. Once this takes place, the recent Cuban free market economic expansions will collapse because they require a consistent flow of American tourists to succeed. ${ }^{57}$ These recent free market experiments include small hotels and private restaurants. ${ }^{58}$

\section{PROPOSAL}

The clear conclusion is that the travel ban must be rescinded to allow Americans to make their own travel decisions. This would reinvigorate the Cuban free market and American investment funds would begin to flow into Cuba. Rescinding the travel ban would encourage growth in Cuban exports. ${ }^{59}$

For American travelers, an unheralded benefit of touring Cuba is to observe the reality of communism. Communism in Cuba means substantial restrictions on travel and food allocation, as well as shortages of goods, oil, and opportunities for the Cuban people ${ }^{60}$ For example, some Cuban

56. Press Release, U.S. Dep't of Treasury, Treasury Sanctions Companies Operating in the Oil Sector of the Venezuelan Economy and Transporting Oil to Cuba (Apr. 5, 2019), https://home.treasury.gov/news/press-releases/sm643 [https://perma.cc/NM55-KJZ6] ("[N]ot only to isolate corrupt Venezuelan enterprises, but also to target Maduro's supporters in Havana who continue to enable the oppression of the people of Venezuela.").

57. See Carmelo Mesa-Largo, There's Only One Way Out for Cuba's Dismal Economy, N.Y. TimES (Mar. 28, 2019), https://www.nytimes.com/2019/03/28/opinion/cuba-economy. html [https://perma.cc/8UXD-NURG].

58. See id.

59. Cuba could export rum, sugar, cigars, and music to the United States. J. Bennett Alexander, Famous Exports to Come Out of Cuba, HolT's ClubHouse (June 10, 2019), https://www.holts.com/clubhouse/cuban-cigars/famous-cuban-exports [https://perma.cc/ XC7Q-C9U4].

60. Id. Allowing freedom of travel for Americans would also carry substantial economic benefits for the United States. According to a 2002 Cuba Policy Foundation study, total U.S. income from the travel would exceed $\$ 545$ million in the first year of erasing the travel ban, and 3,797 new jobs would be added. Id. By the fifth year, total income would rise to over $\$ 1.9$ billion, with 12,180 new jobs. Id. The largest income and job generators would be U.S. airlines, the cruise industry, and fast ferry service providers. Id. Furthermore, "The induced and indirect income and employment generated from these primary industries would ... spread widely throughout the U.S. economy as travel industries and employees purchased needed products and services." Id. For example, U.S. car rental companies and U.S. chain restaurants would likely invest in the Cuban market, as would companies providing everyday American-made items, such as medicines. Id. In the travel sector, as in the trade and investment sectors, the United States would do well to pursue the rich opportunities awaiting it. $I d$. 
doctors drive cabs because it pays more than working as doctors. ${ }^{61}$ Prior to the travel ban, there were shortages of nearly everything - most food, pharmaceuticals, and car parts. ${ }^{62}$ For instance, many of the beautiful old American cars depicted in photos of Cuba emit fumes because they use Russian diesel motors. ${ }^{63}$ American engines and car parts are not available. ${ }^{64}$

The U.S. travel ban will also lead to increased food shortages. ${ }^{65}$ While visiting Cuba in 2017, beef was practically not available. Each family received only a few eggs per month by the end of each month, there were shortages of most foods. The travel ban will likely exacerbate these shortages because it will reduce the flow of cash into Cuba.

The Cuban embargo should be terminated. ${ }^{66}$ Although the President of the United States has the authority to set foreign policy, multiple sources of law-including human rights law, rules of the United Nations, and the Fifth Amendment-suggest the travel ban is overreaching and will be counterproductive. ${ }^{67}$

61. Rob Waters, The Cuban Hustle: Doctors Drive Cabs and Work Abroad to Make Up for Meager Pay, STAT NEws (Feb. 8, 2017), https:/www.statnews.com/2017/02/08/ cuba-doctors-meager-pay/ [https://perma.cc/7LXD-E8BR].

62. Scott Beyer, Havana Cuba - The City of Scarcity, Mkt. Urbanism ReP. (Aug. 30, 2018), https://marketurbanismreport.com/blog/havana-cuba-the-city-of-scarcity [https:// perma.cc/LQ5S-2G6D] (personal account on shortages of supplies in Havana); Shortages of Basic Products have Cubans Worried, HAVANA Times (Feb. 22, 2020), https://havanatimes.org/ features/shortages-of-basic-products-have-cubans-worried/ [https://perma.cc/T5UW-M22C].

63. Phillippe Diederich, Voices: Cuba's Vintage Cars Are Cool, But Not Their Exhaust, NBC News (July 5, 2016, 9:16 AM), https://www.nbcnews.com/news/latino/voices-cubas-vintage-cars-are-cool-not-their-exhaust-n603951 [https://perma.cc/K429-Z2SC].

64. See Jonathan Harper, Here's What Cuba's Car Scene Looks Like in 2017, JALOPNIK (Feb. 3, 2017, 11:27 AM), https://jalopnik.com/heres-what-cubas-car-scenelooks-like-in-2017-1791963244 [https://perma.cc/CKF3-5Z47] ("A dissolved U.S. embargo could flood the Cuban market with relatively cheap new American cars, which could in turn greatly reduce the numbers of these pre-revolution Franken-cars.").

65. Michael Weissenstein \& Andrea Rodriguez, Cuba Launches Widespread Rationing in Face of Crisis, AP News (May 10, 2019), https://apnews.com/42b62f24be9b4e0d9f 764fla3fa9647a [https://perma.cc/J2VY-3HEC]; Shortages of Basic Products Have Cubans Worried, HAVANA TimES (Feb. 22, 2020), https://havanatimes.org/features/shortages-ofbasic-products-have-cubans-worried/ [https://perma.cc/T5UW-M22C].

66. Daniel Hanson et al., It's Time For The U.S. To End Its Senseless Embargo of Cuba, ForBes (Jan. 16, 2013, 8:36 AM), https://www.forbes.com/sites/realspin/2013/ 01/16/its-time-for-the-u-s-to-end-its-senseless-embargo-of-cuba/?sh=5e7c7b2e2347 [https:// perma.cc/HD5D-2AH6] (explaining that the United States is the only country restricting access to Cuba and has been condemned annually by the United Nations since 1992 for the embargo).

67. Mr. President, you have a unique opportunity to step up and tell the world and the children of the former landowners of Cuba that you will end the embargo now in order to grow the economies of the United States and Cuba. Tell them the "Cold War" is officially over, we are economic friends with China and Russia, and we should also be economic friends with our close neighbor, Cuba. See MATTHEW EVANGELISTA, UNARMED ForCES: The Transnational Movement to End The Cold War 11 (1999). ("Leaders of NATO, 


\section{CONCLUSION}

Americans and Cubans hope the ban will end soon. ${ }^{68}$ Americans wish for an end to the ban so that they may visit Cuba. Airlines and cruise ships also seek an end to the ban because of the economic benefits derived from resuming their transportation operations. For Cubans, an end to the ban would mean an increase in cash from U.S. tourism, which would help to boost prosperity. Cubans live with the understanding that their entire future lies with the U.S. embargo being lifted, but they have no expectations that anything will improve. ${ }^{69}$ Cubans understand that the President of the United States holds the future of Cuba in the palm of his hand.

the Warsaw Pact, and a dozen nonaligned European countries ... met in Paris in November 1990 to sign the CFE treaty. They declared a formal end to the Cold War."). To encourage economic development in Cuba, and simultaneously bring substantial economic benefits to the United States, the U.S. government should fully recognize Cuba and lift the embargo that it initiated in 1960. Frank J. Vandall \& Emily Quan, An Economic Analysis of Lifting the Cuban Embargo, ATINER CONF. PAPER SERIES 6 (2012), https://www.atiner.gr/papers/ LAW2013-0852.pdf [https://perma.cc/923H-2U8Z].

68. Nelson Acosta, Cubans Applaud Biden Win, Hope for Easing of Sanctions, REUTERS (Nov. 7, 2020), https:/www.reuters.com/article/us-usa-election-cuba/cubansapplaud-biden-win-hope-for-easing-of-sanctions-idUSKBN27N0Z5 [https://perma.cc/ 7MX4-RBVP]; Carmen Sesin, Cuban Americans Brace for Tougher Travel After Trump's New Restrictions, NBC News (Nov. 1, 2019, 10:01 AM), https://www.nbcnews.com/news/ latino/cuban-americans-brace-tougher-travel-after-trump-s-new-restrictions-n1073996 [https://perma.cc/6WE9-YXRU].

69. Acosta, supra note 68. 
